Лепіхов А. B . (ORCID: ID 0000-0003-0745-8113);

Храпач Г. С. ${ }^{2}$ (ORCID: ID 0000-0002-1089-1535)

1 - Національний інститут стратегічних досліджень, Київ;

2 - Центр воєнно-стратегічних досліджень Національного університету оборони України імені Івана Черняховського, Київ

\title{
Стратегія непрямих дій як інструмент геополітичного протиборства у сучасних умовах
}

Резюме У науковій статті розкрито сутність стратегії непрямих дій. Розглянуто фактори розвитку людства, які вплинули на актуалізацію застосування зазначених стратегій суб'єктами геополітичного протиборства у сучасних умовах. Розкрито сутність гібридних загроз як елементу реалізації стратегій непрямих дій. На основі системно-діяльнісного підходу запропоновано модель розроблення та реалізації стратегії непрямих дій.

Ключові слова: стратегія непрямих дій; державна безпека; зовнішня політика; міжнародні відносини; гібридні загрози; геополітичне протиборство.

Постановка проблеми. Інноваційні М. Воротнюк, М. Шевченко та інші [3-9, 12технології міждержавного протиборства у 18, 22-24]. Серед іноземних науковців вирішальній мірі породжують нові виклики та зазначену тематику досліджували: Р. Арон, загрози міжнародній безпеці. За таких умов, М. Келдор, Ф. Хофман, Е. Лютвак, Ф. Фукуяма, актори міжнародних відносин змушені протидіяти новим загрозам сучасності, які переважно мають трансграничний (гібридний) вимір i, як правило, є результатом реалізації суб'єктами геополітичних протиборств стратегій непрямих дій, які засновані на принципах управління конфліктами. Зазначений фактор $є$ дестабілізуючим чинником міжнародної обстановки та джерелом загроз безпеці сучасних держав.

Наукове дослідження підходів до розроблення і реалізації стратегій непрямих дій, як інструменту зовнішньої та безпекової політики сучасних центрів сили дає змогу вирішити завдання - удосконалення наявних та напрацювання нових методів і форм виявлення й протидії зовнішнім загрозам національній безпеці України, підготовки ефективних механізмів захисту від геополітичної експансії вагоміших акторів.

Аналіз останніх досліджень і публікацій. На підставі аналізу актуальних досліджень і наукових публікацій вітчизняних і зарубіжних науковців можна дійти висновку, що у рамках філософії, політології, безпекознавства i воєнної науки приділено значну увагу дослідженню проблем стратегічних підходів до реалізації зовнішньої політики держави і забезпечення національної безпеки, формуванню геостратегії країни на світовій арені, сучасних форм ведення війни i геополітичного протиборства. Зокрема, ці наукові проблеми досліджували такі вітчизняні науковці, як В.Горбулін, В. Смолянюк, В. Мартинюк, Г. Почєпцов,

С. Хентінгтон, З. Бзежинський, Є. Месснер, T. Томас, Б. Ліделл-Гард та інші [1, 2, 10, 11, 19-21].

Незважаючи на значний науковий доробок дослідників 3 актуальних проблем загроз національній безпеці маємо констатувати про обмаль наукових праць в яких би комплексно розглядали питання теоретичних засад розроблення стратегій непрямих дій, формування гібридних загроз (у рамках реалізації зазначених стратегій) та управління останніми як інструментарієм досягнення геополітичних цілей в сучасних умовах геополітичного протиборства.

Саме тому, метою статті $\epsilon$ розгляд стратегії непрямих дій як інструментарію геополітичного протиборства в сучасних умовах міжнародної конфліктності та побудова в межах системно-діяльнісного підходу моделі розроблення та реалізації стратегії непрямих дій.

Виклад основного матеріалу. Британський воєнний теоретик Б. Ліделл-Гард стверджував, що стратегію непрямих дій не доцільно сприймати лише через призму концепцій війни [10]. На його думку, методи непрямих дій $є$ ключем до практичного вирішення будь-якої проблеми, в якій основоположними чинниками $\epsilon$ людина та суперечність інтересів, що призводить до конфліктності. Історія стратегічної думки, за сутністю, є літописом удосконалення методу непрямих дій, який заснований на стратегічному мисленні i психологічному протиборстві (впливом одного розуму на 
іншій), вибору найоптимальніших підходів до розв'язання проблеми, здобуття переваги та раціонального використання ресурсів відповідно до обставин i зорієнтований на подолання або “обхід" сили опору супротивника у процесі досягнення тієї чи іншої мети в умовах конкурентності [10].

Вітчизняний дослідник М. Шевченко під поняттям “стратегія непрямих дій” пропонує розуміти систему симетричних та асиметричних підходів і комплекс дій активної сторони (держави, союзу), які призводять у перспективі до умов успішної реалізації іiі політики щодо відстоювання інтересів через створення ситуації дезорієнтації супротивника в контексті діалектичних змін простору протиборства [16,23]. Крізь призму геополітичного i геоекономічного підходів, цей процес відбувається за допомогою системної реалізації заходів опосередкованого стратегічного впливу на об'єкт-експансії, що передбачає, серед іншого, формування гібридних загроз супротивнику. У воєннополітичному контексті, головна мета такої стратегії - послабити опір супротивника наперед, ніж робити спробу долати його, “роззброїти” ворога і спонукати його виконати волю переможця [22].

у Спільному рамковому документі Європейського Союзу з протидії гібридним загрозам від 06.04.2016 “гібридні загрози” визначено як поєднання примусової та підривної діяльності, традиційних i нетрадиційних методів (дипломатичних, військових, економічних, технологічних тощо), які можуть бути скоординовано використані державними чи недержавними суб'єктами для досягнення конкретних цілей, залишаючись на рівні нижче порогу формально оголошеної війни. У Спільній доповіді Свропейського парламенту i Європейської Ради від 19.07.2017 поняття “гібридна загроза" визначено як явище, що виникає внаслідок конвергенції та взаємозв'язку різних елементів, які разом утворюють складнішу та багатовимірну загрозу [12, с.17-18].

\section{Вбачається,} що актуалізація застосування стратегій непрямих дій як інструментарію досягнення геостратегічних цілей на міжнародній арені набули вагомості через еволюційний вплив на розвиток людства процесів глобалізації i технологічного прогресу, появу на межі XX-XXI століть сучасних парадигм війни та у зв'язку 3 поступовим переходом міжнародних відносин 3 геополітичної на геоекономічну парадигму світового розвитку. За таких умов стратегії високорозвинених держав постіндустріальної цивілізації (міжнародні відносини яких грунтуються на геоекономічній парадигмі) стали вже непов'язаними із завоюванням територій, i навіть із прямим підкоренням економічного простору інших країн. Вони швидше стали націленими на нав'язування у системі міжнародних відносин своєї політичної волі та бачення майбутнього, на встановлення й досягнення стратегічних горизонтів, які визначаються геоекономічною конкуренцією і масштабами управління ризиками, на зміцнення чи підрив тієї чи іншої системи соціально-економічних орієнтацій [7, с. 430$431 ; 16]$.

На думку 3. Бзежинського i С. Хантінгтона, у сучасному світі виникнення класичних повномасштабних війн $\epsilon$ маловірогідним через зростання ролі наднаціональних інституцій $\mathrm{i}$ міжнародного права, розвиток глобальної ринкової економіки, існування ядерного збройного паритету, значну трагічність i витратність повномасштабних війн. Водночас через зростання на межі глобальних економічних криз геоекономічної конкуренції за планетарні ресурси і ринки збуту товарів та послуг, у високорозвинених держав виникає потреба у створені відповідних переваг над геополітичними опонентами, що породжує відповідну конфліктність у системі міжнародних відносин. Отже потреба держав у військовій силі зростає. Заразом через занепокоєння міжнародно-правових інституцій, уряди держав не завжди готові застосувати національні регулярні армії та нести відповідальність за можливі негативні наслідки від відкритої військової агресії. Отже для розв'язання зазначеної проблеми урядами таких держав та іншими глобальними недержавними акторами здійснюється пошук нестандартних способів досягнення геостратегічних чи геоекономічних цілей $[1,2,17,20]$.
Вітчизняні
науковці
М. Воротнюк, Г. Почепцов, Г. Ситник, М. Шевченко, В. Смолянюк та іноземні дослідники Ф. Каппен, Ф. Хофман, Е. Лютвак та інші, вважають, що образ сучасної війни носить локальний характер, визначається таким явищем, як поєднання обмеженого силового впливу на супротивника із застосуванням стратегії непрямих дій. Основні типи майбутніх конфліктів - асиметричні конфлікти низької і середньої інтенсивності. В їх основі закладені формування гібридних загроз для “держав- мішеней”, які мають комбіновані змістовні 
виміри (синергія традиційних, нетрадиційних, глобальних загроз). Особливістю $є$ факт опосередкованого управління цими загрозами державою-агресором (або глобальними недержавними акторами), яка таким чином реалізує сценарій силового відстоювання i просування геостратегічних інтересів, залишаючись на рівні нижче порогу формально оголошеної війни “державі мішені”. Характер цього сценарію може об'єднувати широкий діапазон ворожих обставин i намірів, а саме: дестабілізацію суспільно-політичної обстановки в країні, застосування іррегулярних військ (озброєних повстанців, воєнізованих банд-формувань, екстремістські налаштованих груп тощо), кібервійну, тероризм, екстремізм, сепаратизм, незаконну міграцію, етнічні та релігійні конфлікти, загрози безпеці критичної інфраструктурі, діяльність транснаціональної організованої злочинності тощо. До того ж використовуються й інші невійськові засоби ведення війни - політичні, дипломатичні, економічні, інформаційні, психологічні тощо. Гібридні загрози формуються заздалегідь визначеним стратегічним замислом. Тактичними цілями $є$ десуверенізація держави, підрив ii національної могутності, позицій i впливу діючого уряду всередині країни та на міжнародній арені та дезорганізація систем державного i воєнного управління [19]. Джерелами загроз можуть бути держави, терористичні організації, екстремістські угруповання, структури транснаціональної організованої злочинності, приватні воєнні компанії, транснаціональні корпорації тощо $[4,9,11,13,14,17,18,21,22]$.

Стратегія непрямих дій реалізуються у комплексі з методами управління рефлексією супротивника. На думку В. Лефевра, в їх основі закладено впровадження комплексних заходів непрямого впливу на рефлексію об'єкта зацікавленості (зокрема, геополітичного опонента) для його опосередкованого спонукання до прийняття рішення, з тієї чи іншої проблеми у вигідному напрямі для ініціатора такого впливу. С. Комов визначив управління рефлексією як комплекс “інтелектуальних" методів інформаційної війни, які застосовуються через невербальний інформаційний контакт між суб'єктом і об'єктом. На думку вченого, для зазначеного виду інтелектуальних війн притаманні такі методи реалізації: “відвернення уваги”, “перевантаження суперечливою інформацією", "розкол коаліцій”, “параліч дій”, “виснаження”, “обман”, “заспокоєння”, “залякування”, “провокація", “пропозиція”, “тиск” тощо. Зі свого боку Ф. Чаусов акцентує увагу на ефективності таких прийомів рефлексивного управління, як дезінформація, провокація, шантаж, компрометація геополітичного супротивника. Проте найсуттєвішою загрозою $\epsilon$ саме дезінформаційні акції, які призводять до заздалегідь спланованих результатів впливу на громадську думку або на осіб, що приймають рішення [19].

Запропонуємо модель розроблення i реалізації стратегій непрямих дій, що використовується тим чи іншим агресором (рис. 1), яка дасть змогу під час майбутніх наукових досліджень визначити підходи до розроблення відповідного державноуправлінського механізму ефективного реагування на зазначену категорію загроз.

Так, вбачається, що для досягнення геополітичних цілей тими чи іншими суб'єктами міжнародних відносин, передбачено формування цілісної інституційної системи, яка включає в себе широке коло формальних (державних) i неформальних (неурядових) суб'єктів публічної політики, національної безпеки і бізнесу (зокрема, транснаціональні корпорації). Ця система функціонує як єдиний механізм стратегічного управління процесами опосередкованого зовнішнього впливу, підсистеми якого органічно взаємопов'язані та взаємодоповнені, об'єднані єдиним стратегічним задумом і алгоритмом діяльності та зорієнтовані на досягнення стратегічних цілей щодо захисту i просування у світі національних інтересів, взаємодоповнені 3 корпоративними інтересами усіх неформальних учасників стратегічної операції. До потенційних суб'єктів такої системи можна віднести:

\section{На держскиому рівні:}

вищі органи державної і політичної влади та управління та їх інституції, дипломатичні установи, окремі впливові державно-політичні діячі;

сили безпеки і оборони (розвідувальне товариство, збройні сили тощо);

державні інформаційно-аналітичні та прогностичні центри;

$$
\text { державні органи планування }
$$

стратегічного впливу; центри мережевого інформаційнокомунікативного управління тощо.

\section{На неурядовому рівні:}

транснаціональні корпорації та 

фонди;

міжнародні неурядові організації i

науково-дослідні та експертні інститути, консалтингові структури, експертноаналітичні групи, національні і міжнародні університети, центри тощо;

компанії у сфері інформаційних комунікацій і мас-медіа;

громадсько-політичні

волонтерські організації,

структури, діаспори тощо; приватні організації сектору безпеки приватні воєнні та охоронні компанії, служби безпеки корпорацій тощо;

окремі фахівці у сфері зовнішньої політики і безпеки, які здійснюють професійну діяльність (незалежні експерти, аналітики, політтехнологи, консультанти) та представники національного i міжнародного політикуму, великого бізнесу, культурної і релігійної еліти, діаспор;

екстремістські організації, організована злочинність, які використовуються скрито i опосередковано.

\section{Схема}

цілісної інституційної системи формальних (державних) і неформальних (неурядових) суб'сктів реалізації стратегії непрямих дій і впливу

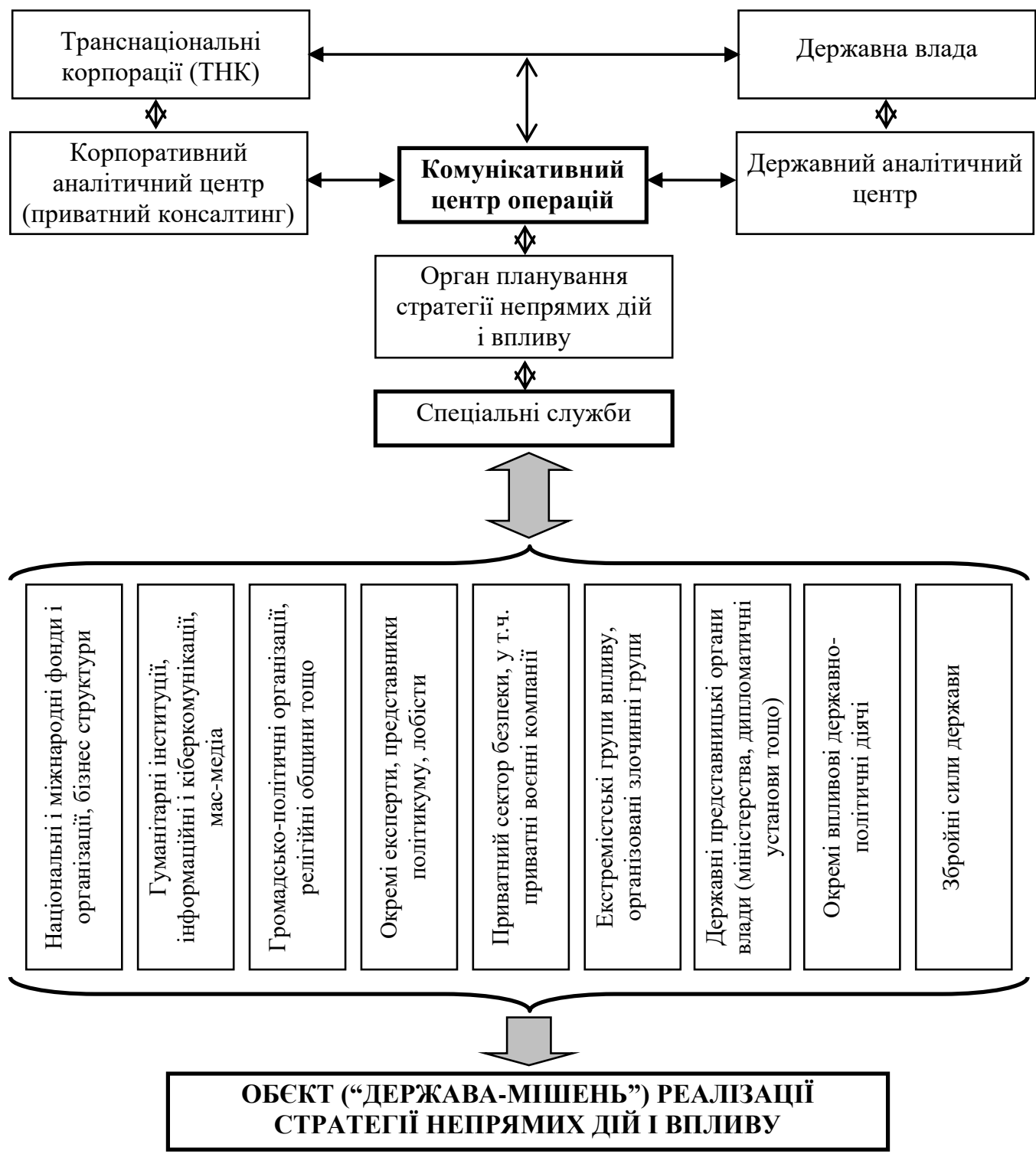

Рис. 1. Модель розроблення і реалізації стратегій непрямих дій

Під час розроблення стратегії формування i реалізації гібридних загроз вагоме значення надається побудові іiі комплементарної моделі. Як стверджують українські науковці
В. Кириленко та
М. Шевченко, компліментарність є сукупністю моделей усіх складових i компонентів реалізації стратегії. Комплементарна модель це інтегральне поняття, що передбачає створення системи орієнтирів і заходів під час 
реалізації зазначених стратегій. Вона $є$ аналогом, схемою, структурою соціальної реальності, пов'язаної з реалізацією стратегій непрямих дій та стратегічного впливу [8].

$$
\text { Узагальнений аналіз наукових }
$$

досліджень проблематики стратегічного управління у сфері національної безпеки вітчизняних науковців В. Горбуліна $[5,6]$, В. Богдановича [3], А. Семенченка [15], Г. Ситника [16, 17], М. Шевченка [22, 23], В. Кириленка [8] Л. Шипілової [24] та інших, дає змогу розкрити деякі погляди на концепцію розроблення і реалізації стратегій непрямих дій та замислів стратегічного впливу на розвиток міжнародної обстановки для досягнення геополітичних цілей. Зокрема, вбачається, що концептуально побудова відповідної комплементарної моделі досягнення геополітичних цілей здійснюється за такими ієрархічними рівнями:

“стратегічний” - цілепокладання;

“організаційний” - цілевизначення;

“функціональний” - цілереалізація.

Ha стратегічному рівні

забезпечується ретельне вивчення об'єктів i суб'єктів стратегічного впливу, їх сильних і слабких сторін, наявних сил i засобів, ресурсних можливостей, інтегральної могутності, стійкості до деструктивних зовнішніх i внутрішніх впливів тощо. Проводиться концептуалізація національних (корпоративних) цінностей та інтересів, які потребують захисту i просування на міжнародній арені, окреслення стратегічних цілей, які необхідно досягти під час реалізації заходів зі стратегічного впливу. Створюється комплементарна модель реалізації стратегій. Проводиться ретельний аналіз зовнішнього середовища у якому реалізовуватиметься цільова стратегія впливу та загроз національним інтересам i безпеці, здійснюється оцінювання ризиків зриву запланованих стратегічних замислів та масштабів можливої шкоди. Формується стратегічний замисел операції. Окреслюються відповідні методичні підходи до вирішення завдання та методи реалізації стратегічного замислу, а також здійснюється вибір інструментів впливу на зовнішнє середовище. Розробляються проекти оптимальних варіантів зовнішньої і воєнної політики держави (союзу держав). Здійснюється попереднє оцінювання відповідності задекларованих цілей наявним ресурсним можливостям i методам їх досягнення. Узгоджуються національні, державні, корпоративні інтереси усіх формальних i неформальних учасників реалізації стратегії впливу. Декларуються i досягаються домовленості щодо захисту i недоторканості стратегічних цілей та збереження їх смислу у рішеннях, які приймаються на всіх рівнях управління протягом усього періоду реалізації стратегічного задуму.

Ha організачійному рівні удосконалюється нормативно-правова база для забезпечення ефективної реалізації цільової стратегії впливу. Здійснюється розроблення i програмно-цільове планування такої стратегії, технології іï реалізації та тактики дій кожного 3 учасників операції. Розробляється ідеологічна основа прикриття істинних цілей стратегічного впливу. Формується ієрархічне дерево цілей (середньострокових, короткострокових), послідовна реалізація яких сприятиме досягненню більш складних - стратегічних (довгострокових) цілей. Здійснюється розподіл функцій та цільових завдань усім суб'єктам системи стратегічного впливу щодо реалізації стратегічних замислів. Формуються організаційні механізми системного управління, контролю, координації й інформаційно-комунікативної взаємодії усіх формальних і неформальних учасників реалізації стратегічного впливу. Відпрацьовуються сценарії їх дій у разі непередбачуваних обставин зміни зовнішнього середовища або форс-мажорних ситуацій та відносної самостійності кожного суб'єкта впливу під час операції i у кризових обставинах. Розробляються механізми забезпечення стійкості системи стратегічного впливу загалом. Здійснюється планування комплексного кадрового, фінансового, матеріального, технічного, інформаційного та іншого забезпечення діяльності усіх суб'єктів (структурних елементів) цієї системи для виконання викладених стратегічних цільових завдань. Проводиться підготовка сил і засобів усіх учасників операції. Зосереджуються зусилля на відборі та композиційній побудові впливу на систему міжнародних відносин на кожному етапі досягнення цілей цієї стратегії. Розглядаються варіанти опосередкованого використання можливостей міжнародних інститутів у питаннях забезпечення зовнішньополітичної безпеки. Організовується функціонування цієї цілісної системи щодо реалізації стратегії впливу.

На функиіональному рівні - реалізуються систематизовані у єдиний алгоритм дій різноманітні багатоходові операції, комбінації, маневри, тактики, прийоми, форми, методи опосередкованого стратегічного впливу i 
конкурентної боротьби. До того ж, для контролю за реалізацією стратегій непрямих дій та впливу, проводиться системний моніторинг і аналіз процесів, які відбуваються в усіх складових сферах системи міжнародних відносин та життедіяльності об'єкта зацікавленості протягом цілереалізації. Здійснюється прогноз розвитку ситуації та, за необхідності, вносяться корективи у стратегію дій. Зорієнтуються зусилля на виявлення поточних зовнішніх і внутрішніх небезпек, загроз i дестабілізаційних чинників, які можуть вплинути на зниження рівня ефективності реалізації стратегії впливу та для недопущення зриву операції вживаються заходи щодо їх нейтралізації. Посилюється контроль за станом воєнно-політичної обстановки, вживаються заходи щодо недопущення зростання ризиків розв'язання війни, що здійснюється за допомогою запровадження відповідних миротворчих, інформаційних дипломатичних та інших заходів. Забезпечується консолідація союзників на спільне проведення у межах концепції “єдиного фронту” заходів проти об’єкта стратегічного впливу (або, навпаки, у разі необхідності, його підтримки) на міжнародному рівні. Зосереджуються зусилля на координації у межах єдиного стратегічного замислу зусиль держави, національного політикуму, бізнесу, культурної еліти, діаспори, громадського суспільства щодо поширення політичного, воєнно-політичного, економічного, культурного впливів на міжнародній арені. Здійснюється підтримка, контроль і управління силами і засобами, які використовуються під час реалізації стратегії непрямих дій i впливу за межами країниініціатора цих процесів. Вживаються заходи щодо інформаційно-пропагандистського супроводження реалізації стратегії впливу, зорієнтованих на формування відповідних стереотипів і установок у соціально-масовому середовищі та поширення комплексу ідей, поглядів, довготривалих програм позиціонування держави i дискредитації геополітичного опонента.

Висновки. Розроблення і реалізація стратегій непрямих дій здійснюються у межах комплементарної моделі за "стратегічним" (цілепокладання); "організаційним" (цілевизначення) i “функціональним” (цілереалізація) ієрархічними рівнями. Передусім формується цілісна інституційна система, яка функціонує, як єдиний механізм стратегічного управління процесами опосередкованого зовнішнього впливу, підсистеми якого органічно взаємопов'язані та взаємодоповнені, об’єднані єдиним стратегічним задумом і алгоритмом діяльності та зорієнтовані на досягнення геополітичних цілей щодо захисту i просування на міжнародній арені національних (чи корпоративних) інтересів. Через призму функціонального підходу, комплементарна модель розробки і реалізації стратегії непрямих дій $\epsilon$ сукупністю розроблених моделей усіх складових елементів зазначеної стратегії (від цілепокладання до цілереалізації). У статті запропоновано підхід до побудови комплементарної моделі розроблення і реалізації стратегії непрямих дій. Упровадження цієї моделі надасть можливість розробити дієві заходи державного реагування на відповідні виклики i небезпеки, які пов'язані з реалізацією зазначених стратегій та породжених ними загроз безпеці держави.

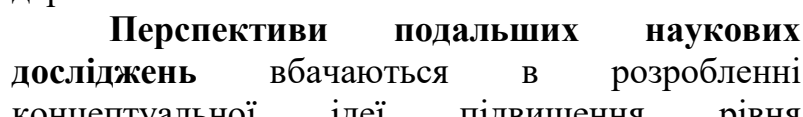
концептуальної ідеї підвищення рівня ефективності реагування системи забезпечення національної безпеки на гібридні загрози, які пов'язані 3 реалізацією більш могутніми геополітичними акторами стратегій непрямих дій стосовно України.

\section{СПИСОК ВИКОРИСТАНОЇ ЛІТЕРАТУРИ}

1. Бзежинский 3. Вне контроля. Глобальний безпорядок на кануне XXI века (1994) [Електронний ресурс] - Режим доступу: https://vunivere.ru/work12948?screenshots=1.

2. Бзежинский 3.: Великая шахматная доска (Господство Америки и его геостратегические императивы).// Книга, г. Вашингтон, округ Колумбия, апрель 1997 года// перевод О. Ю. Уральский // переиздат - М. : Междунар. отношения, 1998. ISBN 5-7133-0967-3 Перевод О. Ю. Уральской// http://hists.narod.ru/doc/new/ knigi/Brzezinski_Velikaja_shachmatnaja_doska.pdf.

3. Богданович В. Ю.: Методика реагування на виклики, небезпеки та загрози національній безпеці держави: навч. посіб. / [авт. кол. :В. Ю. Богданович, А. І. Семенченко, Д. Я. Кучма, А. В. Дацюк]. - К. : НАДУ, 2009. - 40 с.

4. Воротнюк М. О. Особливості міжнародних конфліктів постбіполярного періоду // Стратегічна панорама. - 4 випуск 2009 рік [Електронний ресурс] - Режим доступу: http://www.niisp.org.ua/default3.php.

5. Горбулін В. П. Світова гібридна війна: український фронт: монографія / за заг. ред. В. П. Горбуліна. - К. : НІСД, 2017. - $496 \mathrm{c}$.

6. Горбулін В. П. Стратегічне планування: вирішення проблем національної безпеки. Монографія / В. П. Горбулін, А. Б. Качинський. - К.:НІСД, 2010. - 288 c.

7. Енциклопедія державного управління : у 8 т. / Нац. акад. держ. упр. при Президентові України; наук.-ред. колегія: Ю. В. Ковбасюк (голова) та ін. - К.: НАДУ, 2011. Т. 1: Теорія державного управління / наук.-ред. колегія: В. М. Князєв (співголова), І. В. Розпутенко (співголова) та ін. $-2011 .-70$ с.

8. Кириленко В. І.: Методологія побудови та використання комплементарної моделі національної економічної безпеки / В. І. Кириленко, М. М. Шевченко // Науковий вісник Дипломатичної академії України. Випуск 22. Зовнішня політика і дипломатія: традиції, тренди, досвід. Частина III. Серія "Економічні науки" / За заг. 
ред. Н. О. Татаренко, В. Г. Ціватого. - Київ, 2015. - С. 40-50.

9. Корниенко С. Генерал Франк Ван Каппен: Путин ведёт в Украине гибридную войну [Електронний ресурс ] - Режим доступу: http://hvylya.net/interview/geopolitics2/general-frank-vankappen-putin-vedet-v-ukraine-gibridnuyu-voynu.html

10. Ліддел-Гарт Б-Г. Стратегия непрямых действий. - М. : ИЛ, 1957. [Електронний ресурс] - Режим доступу:http://militera.lib.ru/science/liddel_hart1/index.ht $\mathrm{ml}$.

11. Лютвак Э. Государственный переворот (практическое пособие) (2012) [Електронний ресурс] Режим доступу: https://mybook.ru/author/edvardlyuttvak/gosudarstvennyj-perevorot-prakticheskoeposobie/read/.

12. Мартинюк В. Гібридні загрози Україні та суспільна безпека. Досвід ЄС і східного партнерства (2018) [Електронний ресурс] - Режим доступу:https://geostrategy.org.ua/ua/analitika/item/1401hibrydni-zagrozy-i-syspilna-bezpeka.

13. Почепцов Г. Г. Из истории понятия гибридной войны в США и России (2015) [Електронний ресурс] - Режим доступу: http://www.academia.edu/17801641/ Из_истории_понятия_гибридной_войны_в_США_и_Р оссии.

14. Почепцов Г. Г. Революция.com. Основы протестной инженерии. [Електронний ресурс] - Режим доступу: http://fictionbook.ru/static/trials/03/00/60/03006095.a4.pdf

15. Семенченко А. I. Методологія стратегічного планування у сфері державного управління забезпеченням національної безпеки України : монографія / ISBN 966-619-117-2. / Національна академія державного управління при Президентові України. - К. : НАДУ, 2008. - 428 с.

16. Ситник Г. П. : Геополітичний аналіз та прогнозування : навч. посіб. / авт.кол. : Г. П. Ситник,
В. Ф. Смолянюк, М. М. Шевченко ; за заг. ред. Г. П. Ситника. - К. : НАДУ, 2014. - Ч. 1. - 180 с.

17. Ситник Г. П. Вплив глобалізації на воєнну сферу та принципові особливості сучасних воєнних конфліктів [Електронний ресурс] - Режим доступу: http://nationalsecurity.org.ua/2016/07/06/vpliv-globalizaciina-voehnnu-sferu-ta-principovi-osoblivosti-suchasnikhvoehnnikh-konfliktiv/.

18. Смолянюк В. Ф. Десуверенізація сучасних держав як наслідок глобалізації (22.04.2015) [Електронний ресурс] - Режим доступу: http://nationalsecurity. org.ua/2015/04/22/desuverenizaciya-suchasnikh-derzhavyak-naslidok-globalizacii/.

19. Томас Т. Л. Рефлексивное управление в России: теория и военные приложения (2002) [Електронний ресурс] Режим http://www.intelros.ru/pdf/stratagemi/Tomas.pdf.

20. Хантингтон С.: Столкновение цивилизаций / книга 2003г..// http://www.ex.ua/19076012.

21.Хофман Ф. Гибридные угрозы (21.10.2013) [Електронний pecypc] - Режим доступу: http://navoine.info/hybriddange.html.

22. Шевченко M. M. Методологічні засади аналізу міждержавного протиборства // Нова парадигма. - Вип. 68 / Гол. Ред. В. П. Бех. - К.: Вид-во НПУ ім. М. Драгоманова, 2007 - С. 125 - 133.

23.Шевченко М. М.: Функції та завдання системи забезпечення національної безпеки України в сучасних умовах// Наукова стаття// Науково-інформаційний вісник Академії національної безпеки//Випуск 3-4(3-4)2014// http://nationalsecurity.org.ua/2015/10/15/funkciï-tazavdannya-sistemi zabezpechennya-nb/.

24. Шипілова Л.М.: Організаційно-правові засади та методологія стратегічного планування забезпечення національної безпеки України: навч. Посіб./авт. Л. М. Шипілова - К.:НАДУ, 2015. - 120 с.

Стаття надійшла до редакційної колегії 21.01.2019

Лепихов А. В. ${ }^{1}$;

Храпач А. С. ${ }^{2}$

1 - Национальный институт стратегических исследований, Киев;

2 - Центр военно-стратегических исследований Национального университета обороны Украины имени Ивана Черняховского, Киев

Стратегия непрямых действий как инструмент геополитического противоборства в современных условиях

Аннотация. В научной статье выяснена сущность стратегии непрямых действий. Рассмотрены факторы развития человечества, которые повлияли на актуализацию применения указанных стратегий субъектами геополитического противоборства в современных условиях. Раскрыта сущность гибридных угроз как элемента реализации стратегий непрямых действий, на основе системно-деятельного подхода предложена модель разработки и реализации стратегии непрямых действий.

Ключевые слова: стратегия непрямых действий; государственная безопасность; внешняя политика; международные отношения; гибридные угрозы; геополитическое противоборство.

\section{A. Lepihov'}

\section{A. Hrapach ${ }^{2}$}

1 - National Institute of Strategic Studies, Kiev;

2 - Center for Military and Strategic Studies of the National Defence University of Ukraine named after Ivan Cherniakhovskyi, Kyiv

\section{The strategy of indirect action as a tool of geopolitical confrontation in modern conditions}

Annotation. The scientific article clarified the essence of the strategy of indirect action. The factors of human development that have influenced the actualization of the use of these strategies by subjects of geopolitical confrontation in modern conditions are considered. The essence of hybrid threats is revealed as an element of the implementation of strategies for indirect actions. A model for the development and implementation of strategies for indirect actions is proposed based on a system-activity approach.

Keywords: indirect action strategy; state security; foreign policy; international relationships; hybrid threats; geopolitical confrontation. 